\title{
(2) Coexpression of EphA10 and Gli3 promotes OPEN ACCESS breast cancer cell proliferation, invasion and migration
}

\author{
Jing Peng, Danhua Zhang
}

Additional supplemental material is published online only. To view, please visit the journal online (http://dx. doi.org/10.1136/jim-2021001836)

Department of General Surgery, The Second Xiangya Hospital, Central South University, Changsha, China

Correspondence to Dr Danhua Zhang, Department of General Surgery, The Second Xiangya Hospital, Central South University, Changsha 410011, Hunan, China: zhangdanhua@csu.edu.cn

Accepted 17 March 2021 Published Online First 14 May 2021

\begin{abstract}
This study investigated the influences of EphA10 and Gli3 on breast cancer (BC) cell proliferation, invasion and migration. Immunohistochemistry was used to reveal the expressions of EphA10 and Gli3 in 18 intraductal carcinomas, 124 invasive carcinomas, 50 paracancerous tissues ( $2 \mathrm{~cm}$ away from the tumor, when possible or available), 50 lobular hyperplastic tissues and 30 normal breast tissues. qRT-PCR and Western blotting were applied to detect the expressions of EphA10 and Gli3 in invasive BC cells (MDA-MB-231, BT20 and Hs578T) and normal human mammary epithelial cells (MCF10A). MDAMB-231 and BT20 cells were transfected with sh-EphA10, sh-Gli3 or sh-EphA10+sh-Gli3. CCK-8 was used to test the proliferation of transfected MDA-MB-231 and BT20 cells. Transwell and scratch assays were used for evaluation of invasion and migration of the transfected cells. EphA10 and Gli3 were highly expressed in invasive carcinomas and invasive BC cells. The expressions of EphA10 and Gli3 were associated with the clinicopathological characteristics and poor prognosis of patients with invasive BC. Knockdown of EphA10 or Gli3 suppressed activities of BC cells. Knockdown of both EphA10 and Gli3 was more effective than knockdown of Gli3 alone. Taken together, coexpression of EphA10 and Gli3 promotes BC cell proliferation, invasion and migration.
\end{abstract}

\section{INTRODUCTION}

In United States, breast cancer (BC) accounts for about $29 \%$ of all new cancer cases in women annually. ${ }^{1}$ Tumor invasion and metastasis are dynamic multistep processes, which contribute to the vast majority of $\mathrm{BC}$-associated mortalities. $^{2}{ }^{3}$ Invasive ductal carcinoma is the most prevalent type of $\mathrm{BC}$, followed by invasive lobular carcinoma and other rare types. Both invasive ductal and lobular BC can be diagnosed by pathological findings. However, the underlying causes of the occurrence and development of $\mathrm{BC}$ remain a mystery. ${ }^{4} \mathrm{BC}$ is heterogeneous in molecular changes, clinicopathologic characteristics, therapeutic responses and clinical outcomes. The initiation of BC is a complicated process characterized by genetic and epigenetic alterations that activate cellular pathways for tumorigenesis. ${ }^{5}$ In spite of notable advances in

\section{Significance of this study}

What is already known about this subject?

- Breast cancer is a highly invasive and heterogeneous malignancy that results in vast mortality.

- EphA10 is highly expressed in breast cancer.

- Gli proteins are implicated in various tumorigenic processes.

What are the new findings?

- EphA10 and Gli3 were both highly expressed in invasive breast carcinomas and cells.

- Positive expressions of EphA10 and Gli3 are associated with poor prognosis of invasive breast cancer.

- EphA10 and Gli3 work in synergy to promote proliferation, migration and invasion of breast cancer cells.

How might these results change the focus of research or clinical practice?

- EphA10 and Gli3 can be concurrently targeted for treatment of breast cancer.

early detection and diagnosis of BC, substantial challenges still remain in preventing the cancer initiation and improving the treatment of BC. ${ }^{6}$ In China, the mortality of patients with $\mathrm{BC}$ has doubled over the last three decades. ${ }^{7}$ Further exploration of the progression of $\mathrm{BC}$ is urgently needed to improve patients' survival. ${ }^{8}$

Eph receptor tyrosine kinases together with their ligands known as ephrins are involved in a large spectrum of developmental processes. ${ }^{9}$ The Eph/ephrin signaling mediates cell-cell interaction and contributes to the tumorigenesis, angiogenesis and metastasis in many cancers. ${ }^{10}$ Eph receptor A10 (EphA10) was characterized as a more efficient biomarker than the established prognostic marker Her-2 in BC. ${ }^{11}$ EphA10 was highly expressed in various BC subtypes, and an anti-EphA10 antibody could significantly suppress tumor growth. ${ }^{12}$ Moreover, both mRNA and protein expressions of EphA10 were positively correlated with tumor metastasis in BC. ${ }^{13}$ Nevertheless, the function of EphA10 in BC cells is uncharacterized. 
The Hedgehog $(\mathrm{Hh})$ signaling pathway, which is well conserved in mammals and other vertebrate species, has long been known to regulate growth and patterning during embryonic development. Hh signaling pathways consist of $\mathrm{Hh}$ proteins (Sonic Hh, Indian $\mathrm{Hh}$, and Desert $\mathrm{Hh}$ ), 12 transmembrane protein patched (patched 1 and patched 2), 7 transmembrane protein smoothened (Smo) and 5-zinc finger transcription factor Gli proteins (Gli1, Gli2 and Gli3). ${ }^{14} 15$ The Gli proteins are large and multifunctional transcription factors. The three members of Gli proteins behave differently with partially redundant functions and are implicated in tumorigenesis. Available data has supported the positive correlation of Gli3 with the progression of hepatocellular carcinoma,${ }^{16}$ colon cancer, ${ }^{17}$ non-small-cell lung cancer, ${ }^{18}$ prostate cancer ${ }^{19}$ and cervical cancer. ${ }^{20}$ However, the role of Gli3 in $\mathrm{BC}$ remains to be clarified.

The expressions of EphA10 and Gli3 were investigated in surgically resected $\mathrm{BC}$ tissues and cultured $\mathrm{BC}$ cells in this study. Synergic effect of EphA10 and Gli3 was observed in the malignant progression of $\mathrm{BC}$.

\section{MATERIALS AND METHODS}

\section{Patients and tissue samples}

One hundred and twenty-four BC tissues, 50 pericancerous tissues, 50 lobular hyperplastic tissues and 30 normal breast tissues from benign lesions were obtained at the Second and Third Xiangya Hospitals, Central South University, from January 2000 to December 2002 and were histologically identified by two pathologists. The tumors were restaged according to the seventh TNM Classification of Malignant Tumors. Classification and histological grade of the cancerous tissues were determined with reference to the WHO classification of tumors.

Clinicopathological data of the intraductal carcinomas and invasive carcinomas are summarized in table 1. Survival data of the 124 patients with invasive BC were collected. The follow-up time for patients was 13 years. Twenty-six

Table 1 Association between clinicopathological characteristics (CPC) and tumor types

\begin{tabular}{|c|c|c|c|c|c|}
\hline \multirow[b]{2}{*}{ CPC } & \multirow[b]{2}{*}{ Case number } & \multirow{2}{*}{$\begin{array}{l}\text { Intraductal carcinoma } \\
\text { Positive number (\%) }\end{array}$} & \multirow{2}{*}{$\begin{array}{l}\text { Invasive carcinoma } \\
\text { Positive number (\%) }\end{array}$} & \multirow[b]{2}{*}{$\chi^{2}$} & \multirow[b]{2}{*}{$P$ value } \\
\hline & & & & & \\
\hline \multicolumn{6}{|l|}{ Age (years) } \\
\hline$\leq 45$ & 81 & $13(72.7)$ & $68(54.8)$ & 1.938 & 0.164 \\
\hline$>45$ & 61 & $5(27.8)$ & $56(45.2)$ & & \\
\hline \multicolumn{6}{|l|}{ Menopausal status } \\
\hline Premenopausal & 80 & $9(50.0)$ & $71(57.3)$ & 0.337 & 0.562 \\
\hline Postmenopausal & 62 & $9(50.0)$ & $53(42.7)$ & & \\
\hline \multicolumn{6}{|l|}{ Pathologic types } \\
\hline I & 22 & $5(27.8)$ & $17(13.7)$ & 11.132 & 0.004 \\
\hline II & 61 & $12(66.7)$ & $49(39.5)$ & & \\
\hline III & 59 & $1(5.6)$ & $58(46.8)$ & & \\
\hline \multicolumn{6}{|l|}{ Tumor size } \\
\hline$\leq 3 \mathrm{~cm}$ & 72 & $15(83.3)$ & $57(46.0)$ & 8.87 & 0.003 \\
\hline$>3 \mathrm{~cm}$ & 70 & $3(16.7)$ & $67(54.0)$ & & \\
\hline \multicolumn{6}{|l|}{ ER } \\
\hline+ & 73 & $14(77.8)$ & $59(47.6)$ & 5.738 & 0.017 \\
\hline- & 69 & $4(22.2)$ & $65(52.4)$ & & \\
\hline \multicolumn{6}{|l|}{ PR } \\
\hline+ & 79 & $15(83.38)$ & $64(51.6)$ & 6.408 & 0.011 \\
\hline- & 63 & $3(16.7)$ & $60(48.4)$ & & \\
\hline \multicolumn{6}{|l|}{ CerB2 } \\
\hline+ & 85 & $7(38.9)$ & $78(62.9)$ & 3.773 & 0.052 \\
\hline- & 57 & $11(61.1)$ & $46(37.1)$ & & \\
\hline \multicolumn{6}{|c|}{ Lymph node metastasis } \\
\hline No & 73 & $17(94.4)$ & $56(45.2)$ & 15.283 & 0.000 \\
\hline Yes & 69 & 1 (5.6) & $68(54.8)$ & & \\
\hline \multicolumn{6}{|l|}{ TNM stage } \\
\hline I+II & 83 & $17(36.4)$ & $66(36.4)$ & 10.081 & 0.014 \\
\hline III+IV & 59 & $1(1.7)$ & $58(70.3)$ & & \\
\hline \multicolumn{6}{|l|}{ EphA10 } \\
\hline+ & & $8(44.4)$ & $76(61.3)$ & 1.846 & 0.174 \\
\hline- & & $10(55.6)$ & $48(38.7)$ & & \\
\hline \multicolumn{6}{|l|}{ Gli3 } \\
\hline+ & & $9(50.0)$ & $69(55.6)$ & 0.202 & 0.653 \\
\hline - & & $9(50.0)$ & $55(44.4)$ & & \\
\hline
\end{tabular}

ER, estrogen receptor; PR, progesterone receptor; TNM, tumor lymph node metastasis. 
patients who survived longer than 13 years were included in the analysis as censored cases.

Pericancerous tissues were collected from the above 50 patients with invasive BC. The age of these 50 patients ranged from 32 to $70(46.5 \pm 9.4)$ years. The pathological examination showed 18 normal breast tissues, 14 mild dysplasia, 10 moderate dysplasia and 8 severe dysplasia cases. Lobular hyperplastic tissues were collected from 50 patients aged from 28 to $60(36.7 \pm 8.4)$ years. The pathological examination showed 16 normal lobular tissues, 19 mild dysplasia, 10 moderate dysplasia and 5 severe dysplasia cases. Normal breast tissues were collected from normal tissues beside 30 breast fibroadenoma and pathologically identified.

All tissues were made into paraffin sections for immunohistochemistry.

\section{Immunohistochemistry}

EnVision Detection Kit (Dako, Carpinteria, California, USA) was used in the experiment. Briefly, the paraffinembedded tissues were cut into $4 \mu \mathrm{M}$ thick sections. Deparaffinized tissue sections were treated with $3 \% \mathrm{H}_{2} \mathrm{O}_{2}$ in dark for $15 \mathrm{~min}$, followed by heat-induced epitope retrieval using sodium citrate buffer at $96^{\circ} \mathrm{C}$ for $30 \mathrm{~min}$. Primary rabbit anti-human EphA10 and Gli3 antibodies (1:100, Dako) were incubated with the tissues for 2 hours. The tissues were treated with Solution A for $30 \mathrm{~min}$ before 3, ' $^{\prime}$-diaminobenzidine staining and hematoxylin counterstaining. Ten random fields of each section $(500$ cells per field) were examined by two observers independently. The final data took an average of the two observations. Positive cases were represented by $25 \%$ or more positive cells.

\section{Cell culture}

Invasive BC cell lines (MDA-MB-231, BT20 and Hs578T) and normal human mammary epithelial cells (MCF10A) were provided by Shanghai Institute of Cell Research, Chinese Academy of Sciences. Dulbecco's Modified Eagle Medium (DMEM, Gibco, Grand Island, New York, USA) used for cultivation of the cells were supplemented with $10 \%$ fetal bovine serum (FBS), $1 \%$ penicillin and 1\% streptomycin.

\section{Cell transfection}

MDA-MB-231 and BT20 cells were transfected with sh-EphA10 $(20 \mu \mathrm{L})$, sh-Gli3 $(20 \mu \mathrm{L})$ or the negative control (sh-NC, $20 \mu \mathrm{L}$ ) (GenePharma, Shanghai, China) using LipoFiter reagent (Hanbio, Shanghai, China). The following experiments were conducted 24 hours after triplicate transfection.

\section{qRT-PCR}

TRIzol reagent (Invitrogen, Carlsbad, California, USA) was used for extraction of total RNA from cells. Concentration and purity of the RNA samples were measured. The concentration of qualified RNA samples was adjusted, and the RNA was reverse-transcribed using a reverse transcription kit (Takara, Tokyo, Japan) and random primers according to the instructions. Gene expression was detected by LightCycler 480 (Roche Diagnostics, Indianapolis, Indiana, USA), and the reaction conditions were set according to

\begin{tabular}{ll}
\hline Table 2 & Primer sequences \\
\hline Name of primers & Sequences \\
\hline GAPDH-F & GCAAGGATGCTGGCGTAATG \\
GAPDH-R & TACGCGTAGGGGTTTGACAC \\
EphA10-F & CCTGGTAGGGCAGCGTTA \\
EphA10-R & CTGACTGGAGTGGCTGAGTC \\
Gli3-F & GGCCATCCACATGGAATATC \\
Gli3-R & TGAAGAGCTGCTACGGGAAT \\
\hline
\end{tabular}

$F$, forward; $R$, reverse.

the instruction of the fluorescent quantitative PCR kit (SYBR Green Mix, Roche Diagnostics). Each sample had three duplicates. The internal reference gene of mRNA was GAPDH. The $2^{-\Delta \Delta \mathrm{Ct}}$ method was used for data analysis. Sequences of the primers are listed in table 2.

\section{Western blotting}

Cells lysed in radioimmunoprecipitation assay lysis buffer (Beyotime, Shanghai, China) were centrifuged for protein extraction. The protein concentration of each sample was measured using a BCA kit (Beyotime) to ensure the same loading amount of each protein sample. Corresponding volume of proteins was mixed with the loading buffer (Beyotime) and heated in a boiling water bath for $3 \mathrm{~min}$. A $10 \%$ sodium dodecyl sulfate-polyacrylamide gel electrophoresis (SDS-PAGE) was performed for protein separation using a SDS-PAGE gel preparation kit (Beyotime). The electrophoresis (1-2 hours) was initiated at $80 \mathrm{~V}$ and switched to $120 \mathrm{~V}$ after bromophenol blue entered the separation gel. The proteins were transferred to a membrane in an ice bath under a $300 \mathrm{~mA}$ current. The transfer of protein was sustained for $60 \mathrm{~min}$. After being rinsed for $1-2 \mathrm{~min}$, the membrane was placed in blocking buffer at room temperature for $60 \mathrm{~min}$ or at $4^{\circ} \mathrm{C}$ overnight. Primary rabbit anti-human GAPDH antibody (internal reference, 5174S, 1:1000, Cell Signaling Technology, Boston, Massachusetts, USA), anti-EphA10 antibody (ab106437, 1-2 $\mu \mathrm{g} / \mathrm{mL}$, Abcam, Cambridge, Massachusetts, USA) and anti-Gli3 antibody (sc-74478, 1:1000, Santa Cruz, Texas, USA) were incubated with the membrane on a shaker at room temperature for 1 hour. The membrane was washed with washing buffer for $3 \times 10 \mathrm{~min}$. The secondary antibody (horseradish peroxidase-labeled goat anti-rabbit IgG, 1:5000, Beijing ComWin Biotech, Beijing, China) was incubated with the membrane at room temperature for 1 hour, followed by another round of membrane washing. The membrane was added with color developing solution, and the protein expression was detected by the chemiluminescence imaging system (Bio-Rad, Hercules, California, USA).

\section{CCK-8 assay}

Suspension of transfected MDA-MB-231 or BT20 cells $(100 \mu \mathrm{L})$ was transferred to a 96-well plate. Each group had three replicate wells. The cells were incubated for 0, 24, 48 and 72 hours before treatment with CCK- 8 reagent $(10 \mu \mathrm{L}$ per well, Dojindo, Tokyo, Japan) for 1-4 hours. The absorbance value was measured at $450 \mathrm{~nm}$. 


\section{Transwell assay}

Transwell inserts $\left(-20^{\circ} \mathrm{C}\right.$, Corning, New York, USA) were taken out to thaw the Matrigel at room temperature. The Transwell inserts and 24-well plate were added with $0.5 \mathrm{~mL}$ of serum-free medium. The culture fluid was removed after 2 hours. MDA-MB-231 and BT20 cells grown at the logarithmic phase were suspended and cultured in 6-well plates. The cells were transfected as mentioned above after reaching 70\%-90\% confluence. Each group had three replicate wells. After 24 hours of cultivation, the cells were trypsinized and washed twice with phosphate buffer saline. The cells were resuspended in serum-free DMEM with an adjusted concentration. The basolateral chamber was added with $600 \mu \mathrm{L}$ of medium containing $10 \%$ FBS, and the apical chamber was added with $100 \mu \mathrm{L}$ of the cell suspension. After 24 hours, the Transwell inserts were taken out and the supernatant was discarded. Cells remaining in the apical chamber were cleaned using a cotton swab. Cells that invaded through the membrane were fixed with 4\% paraformaldehyde for $20 \mathrm{~min}$ before Wright-Giemsa staining. Number of the cells in five random fields of view was counted under a microscope at high magnification and the cells were photographed.

\section{Scratch assay}

MDA-MB-231 and BT20 cells grown at the logarithmic phase were suspended and evenly inoculated in six-well plates. The cells were transfected as stated after 24 hours. A line was vertically scratched in the cell layer using a sterile pipette $(100 \mu \mathrm{L})$. The scratch width of each group was basically the same. The scratch area at start was recorded as the control. The cells were photographed before and after 24-hour cultivation.

\section{Statistical analysis}

SPSS V.17.0 and GraphPad V.7.0 were used. Data are shown in the form of mean \pm SD. $\chi^{2}$ test was used for analysis of the relationship between EphA10/Gli3 and clinical factors of BC. Kaplan-Meier and log-rank tests were applied for analysis of the patient survival. A Cox proportional hazards model was established for multivariate analysis. $t$-test and one-way analysis of variance were used for comparisons between two groups and among multiple groups. Tukey's multiple comparisons test was performed for post hoc multiple comparisons. Significant statistics were represented by $\mathrm{p}<0.05$.

\section{RESULTS}

\section{Expressions of EphA10 and Gli3 in invasive BC, intraductal $B C$, pericancerous tissues, lobular hyperplastic tissues and normal breast tissues}

Immunohistochemistry showed that EphA10 and Gli3 were located in the cytoplasm (online supplemental figure S1A-B). EphA10 and Gli3 were positively expressed in over $55 \%$ of the 124 invasive carcinomas and in over $44 \%$ of the 18 intraductal carcinomas (table 3). Positive expressions of EphA10 and Gli3 were found in less than 24\% of the 50 pericancerous tissues and 50 lobular hyperplastic tissues (table 3). EphA10 and Gli3 were negatively expressed in all 30 normal breast tissues (table 3 ). The expressions of EphA10 and Gli3 in invasive carcinomas were significantly
Table 3 Expressions of EphA10 and Gli3 in invasive BC, intraductal BC, peritumoral tissues, lobular hyperplastic tissues and normal breast tissues

\begin{tabular}{llll}
\hline Tissue type & $\begin{array}{l}\text { Case } \\
\text { number }\end{array}$ & $\begin{array}{l}\text { EphA10 positive } \\
(\%)\end{array}$ & Gli3 positive (\%) \\
\hline Invasive carcinoma & 124 & $76(61.3)$ & $69(55.6)$ \\
\hline Intraductal carcinoma & 18 & $8(44.4)$ & $9(50.0)$ \\
\hline Pericancerous tissues & 50 & $11(22.0)^{*}$ & $12(24.0) *$ \\
\hline Lobular hyperplastic tissues & 50 & $10(20.0)^{*}$ & $10(20.0) *$ \\
Normal breast tissues & 30 & $0(0.0) *$ & $0(0.0)^{*}$ \\
\hline
\end{tabular}

${ }^{*} p<0.01$, compared with invasive carcinoma.

$\mathrm{BC}$, breast cancer.

higher than those in pericancerous tissues, lobular hyperplastic tissues and normal tissues (table 3, p <0.01). Pericancerous tissues and loublar hyperplastic tissues with positive EphA10 and/or Gli3 expression exhibited certain degree of dysplasia. The positive rates of EphA10 and Gli3 were not significantly different in invasive carcinomas and intraductal carcinomas (table 3, $\mathrm{p}>0.05$ ).

\section{Comparisons of intraductal and invasive BC}

Invasive carcinomas had significantly stronger association with advanced histological grade (grade III), large tumor diameter $(>3 \mathrm{~cm})$, negative estrogen receptor $(\mathrm{ER}) /$ progesterone receptor (PR) and advanced lymph node metastasis (table $1, \mathrm{p}<0.05$ ). The expression of EphA10 or Gli3 had no significant difference in intraductal carcinomas and invasive carcinomas (table $1, \mathrm{p}>0.05$ ).

\section{Expressions of EphA10 and Gli3 are associated with the clinical factors of invasive BC}

EphA10 and Gli3 showed higher positive rates in cases with histological grade III, lymph node metastasis and advanced TNM stage (table 4, $\mathrm{p}<0.05$ ). The expressions of EphA10 and Gli3 exhibited no significant association with patient age, menopausal status, tumor diameter, ER, PR and CerbB2 status (table 4, p>0.05). Among the 76 cases with positive EphA10 expression, 52 cases also had positive Gli3 expression. Among the 48 cases with negative EphA10 expression, 31 cases also exhibited negative Gli3 expression. The expression of EphA10 was positively correlated with that of Gli3 $\left(\chi^{2}=12.984, p=0.000\right)$.

\section{Correlation of EphA10/Gli3 expression with patient survival}

Ninety-eight patients died within 13 years and patients (26 cases) who survived longer than 13 years were included in the analysis as censored cases. Kaplan-Meier survival analysis showed that the mean survival of patients with invasive BC was linked to the histological grade (grade III), tumor diameter $(>3 \mathrm{~cm})$ and advanced tumor metastasis (table 5, p<0.05). Positive EphA10 or Gli3 expression was associated with poor survival of patients with BC (table 5, online supplemental figure S2, $\mathrm{p}=0.000)$. Cox multivariate analysis also showed that the abovementioned factors displayed negative correlations with the overall survival of patients with BC. Additionally, both EphA10 and Gli3 acted independently in the prognosis of $\mathrm{BC}$ (table 6, p<0.05). Finally, we calculated the area under receiver operating 
Table 4 Expressions of EphA10 and Gli3 are associated with the clinicopathological characteristics (CPC) of invasive BC

\begin{tabular}{|c|c|c|c|c|c|c|c|}
\hline \multirow[b]{2}{*}{ CPC } & \multirow[b]{2}{*}{ Case number } & \multicolumn{3}{|c|}{ EphA10 } & \multicolumn{3}{|c|}{ Gli3 } \\
\hline & & Positive number (\%) & $\chi^{2}$ & $P$ value & Positive number (\%) & $\chi^{2}$ & $P$ value \\
\hline \multicolumn{8}{|l|}{ Age (years) } \\
\hline$\leq 45$ & 68 & $43(63.2)$ & 0.24 & 0.624 & $43(63.2)$ & 3.515 & 0.061 \\
\hline$>45$ & 56 & $33(58.9)$ & & & $26(46.4)$ & & \\
\hline \multicolumn{8}{|l|}{ Menopausal status } \\
\hline Premenopausal & 71 & $46(64.8)$ & 0.857 & 0.355 & $45(63.4)$ & 4.027 & 0.045 \\
\hline Postmenopausal & 53 & $30(56.6)$ & & & $24(45.3)$ & & \\
\hline \multicolumn{8}{|l|}{ Histologic grades } \\
\hline I & 17 & $7(41.2)$ & 12.512 & 0.002 & $6(35.6)$ & 15.254 & 0.000 \\
\hline II & 49 & $24(48.9)$ & & & $20(40.8)$ & & \\
\hline III & 58 & $45(77.6)$ & & & $43(74.5)$ & & \\
\hline \multicolumn{8}{|l|}{ Tumor size } \\
\hline$\leq 3 \mathrm{~cm}$ & 57 & $30(52.6)$ & 3.334 & 0.068 & $27(47.4)$ & 2.928 & 0.087 \\
\hline$>3 \mathrm{~cm}$ & 67 & $46(68.7)$ & & & $42(62.7)$ & & \\
\hline \multicolumn{8}{|l|}{ ER } \\
\hline+ & 59 & $30(50.8)$ & 5.174 & 0.023 & $29(49.2)$ & 1.922 & 0.166 \\
\hline- & 65 & $46(70.8)$ & & & $40(61.5)$ & & \\
\hline \multicolumn{8}{|l|}{ PR } \\
\hline+ & 64 & 38 (59.4) & 0.205 & 0.651 & $37(57.8)$ & 0.252 & 0.616 \\
\hline - & 60 & $38(63.3)$ & & & $32(53.3)$ & & \\
\hline \multicolumn{8}{|l|}{ CerB2 } \\
\hline+ & 78 & $48(61.5)$ & 0.005 & 0.941 & $44(56.4)$ & 0.05 & 0.823 \\
\hline- & 46 & $28(60.9)$ & & & $25(54.3)$ & & \\
\hline \multicolumn{8}{|c|}{ Lymph node metastasis } \\
\hline No & 56 & $27(48.2)$ & 7.359 & 0.008 & $25(44.6)$ & 5.008 & 0.025 \\
\hline Yes & 68 & $49(72.1)$ & & & $44(64.7)$ & & \\
\hline \multicolumn{8}{|l|}{ TNM stage } \\
\hline $\mathrm{I}+\mathrm{II}$ & 66 & $30(45.5)$ & 14.914 & 0.000 & $23(34.9)$ & 24.726 & 0.000 \\
\hline $\mathrm{III}+\mathrm{IV}$ & 58 & $46(79.3)$ & & & $46(79.3)$ & & \\
\hline
\end{tabular}

$\mathrm{BC}$, breast cancer; ER, estrogen receptor; PR, progesterone receptor; TNM, tumor, node, metastasis.

characteristic curve (AUC) for EphA10 (AUC=0.706, 95\% CI: 0.617 to 0.796 ) and Gli3 (AUC $=0.678,95 \% \mathrm{CI}$ : 0.587 to 0.770 ) (online supplemental figure S3).

EphA10 and Gli3 are highly expressed in invasive BC cells qRT-PCR and Western blot analysis showed that EphA10 was highly expressed in invasive BC cells (MDA-MB-231, BT20 and Hs578T) compared with normal mammary epithelial cells (MCF10A) (online supplemental figure S4A-B, p<0.05). Gli3 was also highly expressed in MDAMB-231, BT20 and Hs578T cells compared with MCF10A cells (online supplemental figure S4C-D, p<0.05).

\section{Knockdown of EphA10 or Gli3 suppresses BC cell proliferation, invasion and migration}

MDA-MB-231 and BT20 cells were transfected with sh-EphA10, sh-Gli3, sh-NC or sh-EphA10+sh-Gli3. The expression of EphA10 was significantly decreased in the sh-EphA10 group compared with the sh-NC group (online supplemental figure $\mathrm{S} 5 \mathrm{~A}-\mathrm{B}, \mathrm{p}<0.01)$. Also, the expression of Gli3 was reduced in the sh-Gli3 group compared with the sh-NC group (online supplemental figure S5C-D, $\mathrm{p}<0.01$ ). The proliferation of MDA-MB-231 and BT20 cells was inhibited in the sh-EphA10 group and sh-Gli3 group compared with the sh-NC group; the cell proliferation was further impeded in the sh-EphA10+sh-Gli3group compared with the sh-Gli3 group (online supplemental figure S5E, $\mathrm{p}<0.05)$. Transwell and scratch assays revealed that the invasion and migration of MDA-MB-231 and BT20 cells were suppressed in the sh-EphA10 group and sh-Gli3 group compared with the sh-NC group; the cell invasion and migration were further inhibited in the sh-EphA10+sh-Gli3 group compared with the sh-Gli3 group (online supplemental figure S5F-G, p<0.05). Taken together, knockdown of EphA10 or Gli3 suppresses the malignant behaviors of BC cells.

\section{DISCUSSION}

The synergic effect of EphA10 and Gli3 in BC was first reported in the present study. Overexpresssion of EphA10 and Gli3 was observed in invasive BC tumors and cells. EphA10 and Gli3 expressions were positively associated with the severity of invasive BC. Moreover, EphA10 and Gli3 promoted the malignant behaviors of BC cells in vitro.

Eph receptors, required for normal morphogenesis, ${ }^{2122}$ are aberrantly expressed in diverse human cancers. ${ }^{23}{ }^{24}$ Among the Eph receptors, EphA10 is a kinase-deficient protein. ${ }^{25}$ Some preclinical trials have revealed the implication of Eph in tumor growth, metastasis and angiogenesis. ${ }^{26-28} \mathrm{~A}$ variety of cell surface proteins, including Eph receptors, are involved in the progression of BC. ${ }^{92}$ EphA10 has recently been reported to have correlation with poor prognosis and metastasis of tumors, and high expression of EphA10 has been found in invasive BC cells. ${ }^{9}{ }^{1329-31}$ Given the deficiency 
Table 5 Correlations of clinicopathological characteristics (CPC) and EphA10/Gli3 expression with the mean survival of patients with invasive $B C$

\begin{tabular}{|c|c|c|c|c|}
\hline CPC & $\begin{array}{l}\text { Case } \\
\text { number }\end{array}$ & Mean survival (years) & $\chi^{2}$ & $P$ value \\
\hline \multicolumn{5}{|l|}{ Age (years) } \\
\hline$\leq 45$ & 68 & $8.22(0.2-13.0)$ & \multirow[t]{2}{*}{0.134} & \multirow[t]{2}{*}{0.714} \\
\hline$>45$ & 56 & $8.99(0.8-13.0)$ & & \\
\hline \multicolumn{5}{|l|}{ Menopausal status } \\
\hline Premenopausal & 71 & $7.97(0.2-13.0)$ & \multirow[t]{2}{*}{2.261} & \multirow[t]{2}{*}{0.133} \\
\hline Postmenopausal & 53 & $9.33(0.8-13.0)$ & & \\
\hline \multicolumn{5}{|l|}{ ER } \\
\hline+ & 59 & $9.75(0.7-13.0)$ & \multirow[t]{2}{*}{1.847} & \multirow[t]{2}{*}{0.174} \\
\hline- & 65 & $7.48(0.2-13.0)$ & & \\
\hline \multicolumn{5}{|l|}{ PR } \\
\hline+ & 64 & $9.02(0.7-13.0)$ & \multirow[t]{2}{*}{0.019} & \multirow[t]{2}{*}{0.891} \\
\hline- & 60 & $8.05(0.2-13.0)$ & & \\
\hline \multicolumn{5}{|l|}{ CerB2 } \\
\hline+ & 78 & $8.17(0.7-13.0)$ & \multirow[t]{2}{*}{0.688} & \multirow[t]{2}{*}{0.407} \\
\hline- & 46 & $9.17(0.2-13.0)$ & & \\
\hline \multicolumn{5}{|l|}{ Histologic grades } \\
\hline I & 17 & $13.51(11.2-13.0)$ & \multirow[t]{3}{*}{61.642} & \multirow[t]{3}{*}{0.000} \\
\hline II & 49 & $11.36(3.0-13.0)$ & & \\
\hline III & 58 & $4.70(0.2-13.0)$ & & \\
\hline \multicolumn{5}{|l|}{ Tumor size } \\
\hline$\leq 3 \mathrm{~cm}$ & 57 & $10.11(1.0-13.0)$ & \multirow[t]{2}{*}{8.604} & \multirow[t]{2}{*}{0.003} \\
\hline$>3 \mathrm{~cm}$ & 67 & $7.19(0.2-13.0)$ & & \\
\hline \multicolumn{5}{|l|}{ TNM stage } \\
\hline $\mathrm{I}+\mathrm{II}$ & 35 & $18.58(7-30)$ & \multirow[t]{2}{*}{57.569} & \multirow[t]{2}{*}{0.000} \\
\hline III + IV & 38 & $11.05(3-30)$ & & \\
\hline \multicolumn{5}{|c|}{ Lymph node metastasis } \\
\hline No & 56 & $10.73(0.8-13.0)$ & \multirow[t]{2}{*}{9.214} & \multirow[t]{2}{*}{0.002} \\
\hline Yes & 68 & $6.77(0.2-13.0)$ & & \\
\hline \multicolumn{5}{|l|}{ Invasion } \\
\hline No & 33 & $17.52(4-30)$ & 17.399 & 0.000 \\
\hline Yes & 67 & $9.87(3-30)$ & & \\
\hline EphA10 & & & & \\
\hline- & 48 & $12.36(3.0-13.0)$ & 30.874 & 0.000 \\
\hline+ & 76 & $6.12(0.2-13.0)$ & & \\
\hline Gli3 & & & & \\
\hline- & 55 & $12.35(2.0-13.0)$ & 37.617 & 0.000 \\
\hline+ & 69 & $5.69(0.2-13.0)$ & & \\
\hline
\end{tabular}

$B C$, breast cancer; ER, estrogen receptor; PR, progesterone receptor; TNM, tumor, node, metastasis.

of kinase activity, the mechanisms for EphA10 activation may explain for its implication in tumorigenesis.

The Hh-related protein Gli3 is implicated in a variety of cancers, but its role in $\mathrm{BC}$ remains elusive. A previous study reported that the three $\mathrm{Hh}$ signaling proteins, including Gli1, Gli2 and Gli3, were correlated with some prognostic factors in BC and Gli2 expression predicted a lower overall survival rate. ${ }^{32}$ Bai et $a l^{18}$ identified Gli3 as a promising prognostic factor in non-small cell lung cancer, and overexpression of Gli3 was crucial for the tumorigenesis. Inactivation of the Gli3 signaling disrupted the interaction between MDM2 and p53 and strongly potentiated p53-dependent inhibition of colon cancer cell growth. ${ }^{17}$ The aforementioned studies provide basis for the rational use of Gli3 antagonist as a novel treatment option for cancers.
Table 6 Multivariate Cox regression analysis of the correlation between EphA10/Gli3 expression and the overall survival of patients with invasive $B C$

\begin{tabular}{|c|c|c|c|c|c|}
\hline \multirow[b]{2}{*}{ CPC } & & \multirow[b]{2}{*}{$P$ value } & \multirow{2}{*}{$\begin{array}{l}\text { Relative } \\
\text { risk }\end{array}$} & \multicolumn{2}{|c|}{$95 \% \mathrm{Cl}$} \\
\hline & & & & Lower & Upper \\
\hline Age (years) & $\leq 45 />45$ & 0.029 & 2.291 & 1.088 & 4.823 \\
\hline $\begin{array}{l}\text { Menopausal } \\
\text { status }\end{array}$ & $\begin{array}{l}\text { Prememopausal } \\
\text { /prememopausal }\end{array}$ & 0.061 & 2.032 & 0.968 & 4.265 \\
\hline Tumor size & $\leq 3 \mathrm{~cm} />3 \mathrm{~cm}$ & 0.028 & 1.859 & 1.070 & 3.228 \\
\hline Histologic grade & I/II/III & 0.000 & 3.543 & 2.213 & 5.673 \\
\hline $\begin{array}{l}\text { Lymph node } \\
\text { metastasis }\end{array}$ & No/yes & 0.020 & 2.521 & 1.158 & 5.490 \\
\hline TNM stage & I/II/III/IV & 0.004 & 1.948 & 1.235 & 3.074 \\
\hline ER & $-1+$ & 0.568 & 0.797 & 0.366 & 1.735 \\
\hline PR & $-1+$ & 0.215 & 0.602 & 0.269 & 1.344 \\
\hline CerB2 & $-1+$ & 0.988 & 1.004 & 0.627 & 1.606 \\
\hline EphA10 & $-1+$ & 0.001 & 2.515 & 1.473 & 4.293 \\
\hline Gli3 & $-1+$ & 0.009 & 1.940 & 1.180 & 3.189 \\
\hline
\end{tabular}

$\mathrm{BC}$, breast cancer; $\mathrm{Cl}$, confidence interval; $\mathrm{CPC}$, clinicopathological characteristics; $\mathrm{ER}$, estrogen receptor; PR, progesterone receptor; TNM, tumor, node, metastasis.

This study showed that EphA10 and Gli3 were highly expressed in invasive BC tissues and cells. Positive EphA10 or Gli3 expression was correlated with severe clinical situations and poor survival of patients with invasive $\mathrm{BC}$. The AUC of EphA10 and Gli3 showed that these two proteins could be considered as targets for early diagnosis and prevention of BC. In vitro experiments further demonstrated that EphA10 or Gli3 promoted the malignant behaviors of BC cells, and coexpression of EphA10 and Gli3 exerted greater carcinogenic effect.

In conclusion, EphA10 and Gli3 are critical promoters in invasive BC. Positive EphA10 and Gli3 expressions are associated with poor prognosis of invasive BC. Moreover, EphA10 and Gli3 promote the malignant behaviors of BC cells.

Acknowledgements Thanks for all the contributors and participants.

Contributors JP and DZ conceived the ideas. JP and DZ designed the experiments. JP performed the experiments. DZ analyzed the data. JP and DZ provided critical materials. JP wrote the manuscript. DZ supervised the study. All the authors have read and approved the final version for publication.

Funding The authors have not declared a specific grant for this research from any funding agency in the public, commercial or not-for-profit sectors.

Competing interests None declared.

Patient consent for publication Not required.

Ethics approval Breast tissues were collected with the approval of the Ethics Committee for Human Research, Central South University following the approved guidelines. The ethics committee approval number of this study is 2019LS (623).

Provenance and peer review Not commissioned; externally peer reviewed.

Data availability statement Data are available in a public, open access repository. The datasets used or analyzed during the current study are available from the corresponding author on reasonable request.

Supplemental material This content has been supplied by the author(s). It has not been vetted by BMJ Publishing Group Limited (BMJ) and may not have been peer-reviewed. Any opinions or recommendations discussed are solely those of the author(s) and are not endorsed by BMJ. BMJ disclaims all liability and responsibility arising from any reliance placed on the content. Where the content includes any translated material, BMJ does not warrant the accuracy and reliability of the translations (including but not limited to local regulations, clinical guidelines, terminology, drug names and drug dosages), 
and is not responsible for any error and/or omissions arising from translation and adaptation or otherwise.

Open access This is an open access article distributed in accordance with the Creative Commons Attribution Non Commercial (CC BY-NC 4.0) license, which permits others to distribute, remix, adapt, build upon this work noncommercially, and license their derivative works on different terms, provided the original work is properly cited, an indication of whether changes were made, and the use is non-commercial. See: http://creativecommons.org/ licenses/by-nc/4.0/.

\section{ORCID iD}

Danhua Zhang http://orcid.org/0000-0002-0586-4284

\section{REFERENCES}

1 Siegel RL, Miller KD, Jemal A. Cancer statistics, 2017. CA Cancer J Clin 2017;67:7-30

2 Ang L, Zheng L, Wang J, et al. Expression of and correlation between BCL6 and ZEB family members in patients with breast cancer. Exp Ther Med 2017; 14:3985-92.

3 Nola S, Sin S, Bonin F, et al. A methodological approach to unravel organspecific breast cancer metastasis. J Mammary Gland Biol Neoplasia 2012;17:135-45.

4 Wang $\mathrm{H}-\mathrm{K}$, Liang J-F, Zheng $\mathrm{H}-\mathrm{X}$, et al. Expression and prognostic significance of Ect2 in invasive breast cancer. J Clin Pathol 2018;71:442-5.

5 Arnutti P, Kotepui M, Asanprakit W, et al. Determination of whole transcription profiles and specific pathways in invasive ductal breast carcinoma. Int $J$ Clin Exp Pathol 2013;6:1112-20.

6 Parker JS, Mullins M, Cheang MCU, et al. Supervised risk predictor of breast cancer based on intrinsic subtypes. J Clin Oncol 2009;27:1160-7.

7 Wang S, Li H, Wang J, et al. Expression of microRNA-497 and its prognostic significance in human breast cancer. Diagn Pathol 2013;8:172.

8 Wang Q, Yao J, Jin Q, et al. LAMP1 expression is associated with poor prognosis in breast cancer. Oncol Lett 2017;14:4729-35.

9 Fox BP, Kandpal RP. Invasiveness of breast carcinoma cells and transcript profile: Eph receptors and ephrin ligands as molecular markers of potential diagnostic and prognostic application. Biochem Biophys Res Commun 2004:318:882-92.

10 Surawska H, Ma PC, Salgia R. The role of ephrins and Eph receptors in cancer. Cytokine Growth Factor Rev 2004:15:419-33.

11 Imai S, Nagano K, Yoshida Y, et al. Development of an antibody proteomics system using a phage antibody library for efficient screening of biomarker proteins. Biomaterials 2011;32:162-9.

12 Nagano K, Maeda Y, Kanasaki S-I, et al. Ephrin receptor A10 is a promising drug target potentially useful for breast cancers including triple negative breast cancers. J Control Release 2014:189:72-9.

13 Nagano K, Kanasaki S-I, Yamashita T, et al. Expression of Eph receptor A10 is correlated with lymph node metastasis and stage progression in breast cancer patients. Cancer Med 2013;2:972-7.
14 Ruel L, Rodriguez R, Gallet A, et al. Stability and association of smoothened, Costal2 and fused with Cubitus interruptus are regulated by hedgehog. Nat Cell Biol 2003:5:907-13.

15 Xuan YH, Jung HS, Choi Y-L, et al. Enhanced expression of hedgehog signaling molecules in squamous cell carcinoma of uterine cervix and its precursor lesions. Mod Pathol 2006;19:1139-47.

16 Hyun J, Wang S, Kim J, et al. Microrna-378 limits activation of hepatic stellate cells and liver fibrosis by suppressing Gli3 expression. Nat Commun 2016;7:10993.

17 Kang HN, Oh SC, Kim JS, et al. Abrogation of Gli3 expression suppresses the growth of colon cancer cells via activation of p53. Exp Cell Res 2012;318:539-49.

18 Bai X-Y, Lin J-Y, Zhang X-C, et al. High expression of truncated GLI3 is associated with poor overall survival in patients with non-small cell lung cancer. Cancer Biomark 2013;13:37-47.

19 Bragina O, Njunkova N, Sergejeva S, et al. Sonic hedgehog pathway activity in prostate cancer. Oncol Lett 2010;1:319-25.

20 Wen S-Y, Lin Y, Yu Y-Q, et al. miR-506 acts as a tumor suppressor by directly targeting the hedgehog pathway transcription factor Gli3 in human cervical cancer. Oncogene 2015;34:717-25.

21 Barrios A, Poole RJ, Durbin L, et al. Eph/Ephrin signaling regulates the mesenchymal-to-epithelial transition of the paraxial mesoderm during somite morphogenesis. Curr Biol 2003;13:1571-82.

22 Holder N, Klein R. Eph receptors and ephrins: effectors of morphogenesis. Development 1999;126:2033-44.

23 Manning G, Whyte DB, Martinez R, et al. The protein kinase complement of the human genome. Science 2002;298:1912-34.

24 Pasquale EB. Eph-Ephrin bidirectional signaling in physiology and disease. Cell 2008;133:38-52.

25 Murai KK, Pasquale EB. 'Eph'ective signaling: forward, reverse and crosstalk. J Cell Sci 2003;116:2823-32.

26 Brantley-Sieders D, Schmidt S, Parker M, et al. Eph receptor tyrosine kinases in tumor and tumor microenvironment. Curr Pharm Des 2004;10:3431-42.

27 Brantley-Sieders DM, Chen J. Eph receptor tyrosine kinases in angiogenesis: from development to disease. Angiogenesis 2004;7:17-28.

28 Pasquale EB. Eph receptors and ephrins in cancer: bidirectional signalling and beyond. Nat Rev Cancer 2010;10:165-80.

29 Nagaraja GM, Othman M, Fox BP, et al. Gene expression signatures and biomarkers of noninvasive and invasive breast cancer cells: comprehensive profiles by representational difference analysis, microarrays and proteomics. Oncogene 2006;25:2328-38.

30 Bai Y-Q, Zhang J-Y, Bai C-Y, et al. Low EphA7 expression correlated with lymph node metastasis and poor prognosis of patients with esophageal squamous cell carcinoma. Acta Histochem Cytochem 2015:48:75-81.

31 Fujimori T, Kato K, Fujihara S, et al. Antitumor effect of metformin on cholangiocarcinoma: in vitro and in vivo studies. Oncol Rep 2015:34:2987-96.

32 Im S, Choi HJ, Yoo C, et al. Hedgehog related protein expression in breast cancer: $\mathrm{gli}-2$ is associated with poor overall survival. Korean J Pathol 2013:47:116-23. 